\title{
Chapter 5 \\ Old Wine in New Bottles? Comparing the Post-War Guest Worker Migration and the Post 1989 Migration from CEE-Countries to EU-Member Countries

\author{
Rinus Penninx
}

\subsection{Introduction}

In the absence of a substantial theory for international migration that would enable to predict how a migration movement would develop, researchers and policymakers have often used migration movements in the past in comparison with those in the present time as a predictive instrument. In this light, the movement of workers from ten Central and Eastern European (CEE) countries to European Union member states in Western and Southern Europe (henceforth the CEES system) after 1990 is often compared to the post-war Guest Worker System (henceforth GWS). In policy circles such an approach is often called: lessons learned from the past.

This approach of using comparison-based predictions is based on the assumption that the units compared are indeed of the same nature. In this case, the first question is whether the two movements that we compare are in point of fact two cross-border labour migration systems that follow the same mechanisms and happened under similar conditions. We will turn to this question in the next section, where I will outline the contours of the two labour migration systems to establish comparability in a broader sense.

For a detailed comparison of the two cases, which will follow in Sect. 5.3 of this chapter, we need a more refined analytical instrument. To establish such an instrument, I draw on the literature on migration theory and, more specifically, on migration systems theory (Fawcett 1989). This literature refers to three sets of factors that are essential for the emergence and continuation of migration systems. The first set implies that there need to be push and pull factors for labour migration to emerge. Push and pull factors encourage individuals to move from one place to another. Economists measure these factors in general terms like wage differentials and work opportunities, where low wages locally act as a push factor and higher wages

\footnotetext{
R. Penninx $(\bowtie)$

University of Amsterdam, Amsterdam, The Netherlands

e-mail: M.J.A.Penninx@uva.nl
} 
elsewhere as a pull factor; high unemployment rates and decreasing job opportunities act as a push factor and the availability of work elsewhere as a pull factor. These factors are necessary conditions for a labour migration system to emerge. But they are not sufficient in and of itself: their mere existence does not lead to migration and not in all cases.

The second set of factors specifies how individuals - existing in the abovementioned economic circumstances - are actually brought into a labour migration system: candidates for migration have to be aware of their own economic situation and of alternatives elsewhere; there have to be networks - often of emigrants that went before them - that help new migrants, as well as intermediaries and facilitators that take away barriers and thus trigger and sustain movements. In well-established labour migration systems such informational and facilitating functions become institutionalised in recruitment systems that involve sending and receiving states, employers and trade unions, employment agencies, et cetera.

The third set of factors refers to regulatory systems of international migration in the countries of origin as well as in the countries of destination. The countries of origin have to allow the exit of citizens on principle (non-exit was rule in communist countries behind the Iron Curtain up until 1989) and in actual practice (e.g. by giving out passports). They may even facilitate labour migration by assisting in recruitment. Countries of destination, for their part, have policies that 'control and regulate' labour inflows: targets or quota may be established for selective groups of workers, as well as for their duration of stay and the conditions of their work set.

These three sets of factors will be described and compared for both labour migration systems. This will enable us to establish if the two systems differ, and on what points and with what consequences.

\subsection{The Contours of Two Labour Migration Systems}

\subsubsection{The Guest Worker Labour Migration System: 1955-1974}

In the immediate aftermath of World War II, Europe had to 'resettle' some 20 million people on the newly established political map (Bonifazi et al. 2008: 113). Apart from these significant internal movements, Europe was predominantly an emigration continent at that time: pre-war emigration to classical destinations like the USA, Canada, Australia, New Zealand and Latin America was resumed in North Western European countries.

This situation started to change in the mid-1950s. Emigration decreased and immigration gained importance, in the form of temporary labour migration. The economic reconstruction after the war was so successful in several Western and North Western European countries that their labour markets needed more workers than available. Particularly unskilled and low-skilled workers were sought for labour-intensive Fordist production processes, such as mining and manufacturing. Some Western European countries, such as Switzerland, Luxembourg, Belgium and 
France, resumed pre-war labour immigration to fill the vacancies at the lower end of their labour markets. For the Federal Republic of Germany, Austria, the Netherlands and Sweden this experience of being attractive for migrant workers was a relatively new concept.

From the mid-1950s on, a labour migration system was built up gradually, attracting workers from the nearest countries in the south - Italy, Spain, Greece and Portugal - and the east - until 1961 from East Germany and following the closing of the Iron Curtain from Yugoslavia (Van Mol and de Valk 2015: 32/33). In the 1960s the system expanded to include Morocco, Algeria, Tunisia and Turkey. While growing, it also became more organised: rules, conditions and procedures were agreed upon in bilateral agreements between the recruiting and sending countries and institutional arrangements and policies were elaborated, both in the sending and in the receiving countries.

The framing of this labour migration as a temporary solution for labour market shortages and the designation of the workers as 'temporary guests' are important characteristics of GWS. All destination countries defined themselves as 'nonimmigration countries' and stressed the temporary nature of the work contracts. The label 'guest worker' openly expressed such expectations. The migrants also saw their work and stay in Europe as temporary. When the number of temporary workers that returned home during the economic recession of 1966-67 turned out to be rather limited, the response of European countries was to develop stricter rules for entrance and access to the labour market (issuing fewer permits) and to start a discussion on the rotation principle to increase the return. Nevertheless, those of the 'temporary workers' who stayed and brought their families grew larger and the resident immigrant population accumulated over the course of time.

The exact number of migrant workers who were involved in this GWS system is difficult to establish. Estimates of the numbers of individuals that left Italy, Spain, Greece, and Portugal alone between 1950 and 1970 vary from 7 to 10 million (Okolski 2012: 33). The number of migrants from Yugoslavia, Turkey and North Africa who travelled to Western Europe for work is probably equally large, or maybe slightly less so because their migration movement started somewhat later. When looking at the whole period, most of the workers returned, yet a significant foreign labour force was built up: Cohen estimates that at the end of the period, in 1974, the FRG counted 2.2 million foreign workers; France 1.9 million; Switzerland 1.0 million; Belgium 0.22 million, and the Netherlands 0.12 million (Cohen 1987: 111-112).

In the early 1970s the limits of the growth of the Fordist industrial economies became manifest and the need to restructure North Western European economies was evident. The first oil crisis of 1973 sped up this restructuring: the closing of certain sectors like mining, the relocation of other labour intensive sectors to lowwage countries and the automation of still other sectors led to a fall in demand for low-skilled work and thus for migrant workers. Switzerland (1970) and Sweden (1972) were the first countries to install an immigration stop for workers, followed by the FRG (1973), the Benelux countries and France in 1974 (Van Mol and de Valk 2015: 35). 
By the mid-1970s GWS as a system of rotating workers had ceased to exist. The halted recruitment and the various policies to promote the return of migrant workers had specific effects for the different immigrant groups. Migrant workers from Southern European countries did return to their countries of origin more often, while those from the Maghreb countries and Turkey did significantly less so. Quite the contrary happened: they started to bring their families to Europe whenever possible. In the FRG, the Netherlands, Belgium, Austria and France populations from North Africa and Turkey grew significantly under the policy category of 'family reunification' and 'family formation' in the second half of the 1970s and in the 1980s.

\subsubsection{Migration from CEE Countries to $\mathrm{EU}$ Member Countries: 1989 - Present}

The collapse of the Iron Curtain in 1989 and the subsequent opening up of the borders for exit induced significant new migration flows from Central and East European (CEE) countries that took various forms and different directions (Black et al. 2010; Okolski 2012; Glorius et al. 2013). First there was a migration corridor to the 'old immigration countries' in North Western Europe, in which two forms of movements took place: that of well-organised legal, albeit limited, bilateral programmes for temporary employment in Germany and other North-Western European countries (Glorius et al. 2013: 7/8) on the one hand, and short-term irregular circular migration - within the bounds of tourist visa - on the other hand. A second migration corridor was one of mostly irregular flows to the new immigration countries in the South: Greece, Italy, Spain and Portugal. These were popular destinations for migrant workers from Romania, Ukraine, Albania and Bulgaria, because they had easy entry and tolerated irregular residence and clandestine work (Engbersen et al. 2010a, b: $8 \mathrm{ff}$ ). Estimates suggest that a net migration outflow of around 3.2 million took place from the ten CEE states via the two migration corridors between 1989 and 2004 (Engbersen et al. 2010a: 9).

The accession of ten new members to the European Union in 2004 marked the beginning of another new era. Eight of these were CEE countries that had been part of the communist bloc: Poland, the three Baltic States, Slovakia, Slovenia, the Czech Republic and Hungary (the A8). Three years later, in 2007, Bulgaria and Romania (the A2) also joined the EU. The effect of these accessions was twofold: on the one hand the migration that had taken place from the ten CEE countries to Western and Southern Europe since 1989 was redefined as EU-internal mobility and legalised under the new regime. On the other hand, the new regime reinforced migration flows from some new member states, particularly Poland, Romania and Bulgaria, to member states in the Western part of the EU whose labour markets attracted workers. 
The EU15 countries responded differently to the accessions: the UK, Ireland, Sweden and Norway (the latter country is not an EU member, but is part of the European Economic Area) opened up their borders immediately in May 2004. Other countries - often backed up by national trade unions - opted for a transition period of five years in which access of workers of the ten accessory countries to the labour market was subject to permits. Some countries even opted for an additional two years extension. These national policies of immediate or delayed free access have shaped intra-European movement significantly.

In terms of flow, Van Mol and De Valk (2015: 43-49) show, first of all, that the scale of intra-European movement increased significantly in the period 2004-08. In 2008 alone, nearly two million EU-citizens moved within the EU (Eurostat 2011), Polish and Romanian migrants making up the bulk of it. Net flows of intra-European migration (immigration minus emigration) amounted to nearly 1.2 million in 2008 (Dhéret et al. 2013: 10). For the whole period and calculated in absolute numbers, Polish migration (primarily to and from Germany and the UK) makes up for the largest share, followed by Romanian migration (primarily to and from Italy and Spain).

As a result migrant populations of the A8 and A2 countries, particularly from Poland and Romania, grew significantly in all of the EU15 member states: while the immigrant population with $\mathrm{A} 8$ and A2 origin in the EU15 states amounted to approximately 1.9 million in 2004, this population had grown to 5.2 million in 2010 (SVR 2013: 51). The case of Poland, having the largest emigration of all CEE countries in absolute terms, reflects this growth: the number of Polish citizens residing in other EU countries rose from 451,000 in May 2002 to 1,860,000 by the end of 2007; of which 690,000 lived in the UK, 490,000 in Germany and 200,000 in Ireland (Fihel and Okolski 2009: 189).

During the economic crisis of 2009-10 net inflows were reduced from 1.2 million to some 300,000. For CEE migration this meant that the migration corridors to the West and to the South were both affected: net emigration was low or negative and immigrant populations in destination countries were somewhat stabilised. After 2010, when the crisis in Southern Europe continued but Northern countries were much less affected, the southern corridor continued to have negative or low net flows (Spain became an emigration country again: Arango 2016), but flows in the western corridor recovered (Dhéret et al. 2013: 10). However, the CEES system as a whole had ceased to grow.

\subsection{Comparing Two Labour Migration Systems}

The brief outlines of the GWS and the CEES do indeed suggest that these systems have some common characteristics that make them comparable at face value. The two systems connect sending countries that have less developed economies, redundant labour and low wages, with receiving countries that have developed economies, labour shortages and attractive wages. The flow sizes of the two systems are 
also significantly alike (both involving millions of workers), although the CEES system was somewhat smaller than the GWS system. And in terms of length of time there is similarity as well: the GWS system covered 2.5 to 3 decades before it stopped as a labour migration system; the CEES system, starting in 1990, until the present day also covers a period of 2.5 decades.

Accepting this comparability at first glance, I will analyse and compare the three sets of factors that are essential for the emergence and continuation of migration systems in more detail: economic development, differences in wages, and (un-) employment in origin and destination countries; systems of information, networks, intermediaries and organisations that mobilise and steer the migration movements, and the national regulatory systems of sending and receiving countries and their differential effects.

\subsubsection{The Development of Economic Push and Pull Factors}

The starting point in both labour migration systems has been a significant difference in economic development and concomitant wage and employment differentials. First we will compare the economic development of the most important countries involved in the two labour migration systems, ${ }^{1}$ using Gross Domestic Product per Capita (ERS International Macro-economic data set that starts in $1969^{2}$ ) as a rough indicator of development: see Table 5.1.

In 1969, Morocco had the lowest GDP within the GWS system, only 5.3 per cent of the GDP of its major country of destination: France. In 1969 the Turkish GDP was 20.2 per cent of that of Germany, the most important country of destination for Turkish workers. The Southern European countries did have better statistics than Morocco and Turkey in that same year, although the numbers varied considerably: Portugal had the lowest GDP, while Italy had reached the highest level of GDP of the Southern European countries (see also Akgündüz 2008: 18 and Rist 1978: 102).

When it comes to other indicators such as unemployment or the activity rate of the population, the data are not truly comparable because they measure different factors in the various countries, but the literature suggests that unemployment (including hidden unemployment) was high in countries like Turkey (Akgündüz 2008; Abadan-Unat et al. 1976) and Morocco, while this was much less the case in the more developed economies of the Southern European countries such as Italy. This smaller potential of migrant workers in the Southern European countries made the official recruitment of guest workers shift to Morocco and Turkey in the late 1960s.

\footnotetext{
${ }^{1}$ Ideally, the average GDP of all countries of destination would be the best quantity to measure: the EU15 average for the CEES system. For the GWS, such data were not available. The next best comparison was the GDP of the largest destination country: the FRG for Turkish migration, and France for migration from Morocco.
}

${ }^{2}$ At www.ers.usda.gov 
Table 5.1 Gross domestic product per Capita in GWS and CEES origin and destination countries: absolute in US \$ and relative (1969-2014). Source: ERS International macro-economic data set at www.ers.usda.gov

\begin{tabular}{l|l|l|l|l|l|l|l|l|l|l}
\hline Country (/Destin.) & 1969 & $\%$ & 1974 & $\%$ & 1990 & $\%$ & 2004 & $\%$ & 2014 & $\%$ \\
\hline Morocco (/France) & 1001 & $\mathbf{5 , 3}$ & 1110 & $\mathbf{4 , 7}$ & 1766 & & 2351 & & 3175 & 7,7 \\
\hline Turkey (/FRG) & 3912 & $\mathbf{2 0 , 2}$ & 4417 & $\mathbf{2 0 , 0}$ & 6194 & & 8258 & & 11,104 & 24,9 \\
\hline Portugal (/France) & 7182 & $\mathbf{3 7 , 8}$ & 10,840 & $\mathbf{4 5 , 6}$ & 16,790 & & 21,795 & & 20,613 & \\
\hline Greece (/FRG) & 12,061 & $\mathbf{6 2 , 3}$ & 15,741 & $\mathbf{7 1 , 3}$ & 19,456 & & 28,288 & & 22,929 & \\
\hline Spain (/France) & 12,847 & $\mathbf{6 7 , 7}$ & 16,771 & $\mathbf{7 0 , 6}$ & 22,190 & & 30,451 & & 29,224 & \\
\hline Italy (/FRG) & 16,354 & $\mathbf{8 4 , 4}$ & 20,537 & $\mathbf{9 3 , 0}$ & 30,857 & & 36,439 & & 33,008 & \\
\hline FRG & 19,374 & & 22,081 & & 32,345 & & 38,641 & & 44,554 & \\
\hline France & 18,987 & & 23,759 & & 32,742 & & 39,998 & & 41,196 & \\
\hline EU15 & 17,362 & & 21,273 & & 30,070 & & 38,076 & & 39,351 & \\
\hline EU28 & 14,497 & & 17,660 & & 24,863 & & 31,937 & & 33,888 & \\
\hline Slovenia (/EU15) & 8420 & 48,5 & 9540 & & 15,558 & $\mathbf{5 1 , 7}$ & 21,051 & $\mathbf{5 5 , 3}$ & 24,016 & $\mathbf{6 1 , 0}$ \\
\hline Czech Rep. (/EU15) & 8109 & 46,7 & 9283 & & 13,980 & $\mathbf{4 6 , 5}$ & 16,831 & $\mathbf{4 4 , 2}$ & 19,953 & $\mathbf{5 0 , 7}$ \\
\hline Estonia (/EU15) & 6768 & 39,0 & 7441 & & 9187 & $\mathbf{3 0 , 6}$ & 13,473 & $\mathbf{3 5 , 4}$ & 17,997 & $\mathbf{4 5 , 7}$ \\
\hline Hungary (/EU15) & 5267 & 30,3 & 6921 & & 9952 & $\mathbf{3 3 , 1}$ & 12,428 & $\mathbf{3 2 , 6}$ & 13,787 & $\mathbf{3 5 , 0}$ \\
\hline Romania (/EU15) & 3887 & 22,4 & 4307 & & 5599 & $\mathbf{1 8 , 6}$ & 6174 & $\mathbf{1 6 , 2}$ & 8200 & $\mathbf{2 0 , 8}$ \\
\hline Poland (/EU15) & 3795 & 21,9 & 4241 & & 5925 & $\mathbf{1 9 , 7}$ & 9487 & $\mathbf{2 4 , 9}$ & 13,854 & $\mathbf{3 5 , 2}$ \\
\hline Bulgaria (/EU15) & 2695 & 15,5 & 2897 & & 4045 & $\mathbf{1 3 , 5}$ & 5206 & $\mathbf{1 3 , 7}$ & 7093 & $\mathbf{1 8 , 0}$ \\
\hline
\end{tabular}

At the receiving end of the GWS, the North Western European countries had recovered from the economic recession of 1966-67 and unemployment was lower than ever and labour shortages were unprecedented. The period 1968-73 became the summit of the GWS system: official recruitment following strict rules had become the dominant way of migrating and Turkey and the Maghreb countries were by now the most important countries of origin.

By 1974, at the end of the GWS system, the relative differences in GDP of Morocco and Turkey had not changed as compared to 1969. By contrast, the Southern European countries had improved their figures significantly, Italy having a GDP that was as almost as high as that of Germany: 93 per cent. The gap between Morocco and Turkey and the destination countries was clearly of a different order than the gaps between the countries in Southern Europe and their destination countries.

Thus, the movement of workers stopped around 1974 by the sudden disappearance of the demand for labour in destination countries, which was followed by a recruitment stop and policy measures to stimulate return. At that moment the push factors (expressed as relative GDP figures) in Morocco and Turkey were equally strong as five years before. In the Southern European countries, however, they had become less compelling. This explains the different reactions of migrant populations after the recruitment stop: fewer migrants from Morocco and Turkey returned than migrants from Southern European countries.

If we compare such relative figures of the GWS system with those in the CEES system (using the average EU15 GDP for destination countries), we see that the 
relative differences between Bulgaria, Romania and Poland in 1990 compare to Turkey in the GWS system in 1969 to a certain extent; the figures for Slovenia and the Czech Republic in 1990 are somewhere between those of Portugal and Greece in 1969, but below the figures for Spain and Italy in that same year.

Between 1990 and 2004, these relative gaps did not change for Bulgaria and Romania: these countries still had the lowest GDP of the CEE countries in 2004. But the relative difference of Poland (25.5 per cent) had changed in a positive way. At the other end of the spectrum, Slovenia and the Czech Republic had the highest GDP.

Ten years later, in 2014, Bulgaria, Romania and Poland still had the lowest GDP of the CEE countries, but the relative differences had diminished, particularly for Poland (35.2 per cent). Slovenia and the Czech Republic had the highest GDP: 61.0 and 50.7 per cent respectively of the average GDP of EU15 countries. (For comparable data in the literature, but with slightly different indicators, see: Galgóczi et al. (2009: 8 ff) and Dhéret et al. (2013: 17 ff) on all CEE countries; on Hungary see Hars 2009; on Romania see Potot 2010; on Bulgaria see Markova 2010).

These figures make clear that within the GWS and CEES systems there were significant differences between the countries of origin: the relative figures of Bulgaria, Romania and Poland were low (meaning wide gaps) and compare well with those of Turkey between 1969-1974 (though Poland did improve significantly over the course of time). The differences between Slovenia's and the Czech Republic's GDP with the average GDP of EU15 countries at the other end are relatively small and quite comparable with the Southern European countries in the GWS system between 1969 and 1974.

The significant GDP differences above are "translated into significant income differentials, which were clearly an important pull factor for EU-10 nationals" (Galgóczi et al. 2009: 10). By contrast, unemployment seems to be a relatively less important driver for movement in these countries, as unemployment rates were more or less in line with the EU average of 9.2 per cent, Poland being the exception with an unemployment rate of 17.9 per cent in 2005 . However, Poland reduced its unemployment from 19.1 in 2004 to 7.1 per cent in 2008 .

In the receiving countries, complementary observations on pull factors indicate that these operated quite differently within the two migration corridors of the CEES system. In the North Western European countries unemployment was relatively high in the 1990s and labour shortages appeared in specific sectors, for which bilateral labour migration programmes were organised. At the same time, these specific labour shortages, specifically in agriculture and horticulture, were filled by irregular short-term work on tourist visa. The migration corridor to the Southern countries, however, was of a different nature: migrants moved irregularly, attracted by work opportunities in the informal sector of the economies of the Southern European countries. The pull factor here was not so much the low unemployment and high wages, but the comparatively easy way to enter a country, find (informal) work and earn a (relatively low) wage. The accession of the A8 and A2 countries in 2004 and 2007 in point of fact regularised the irregular work and residence situation of CEE migrants if that had not happened by amnesties before. 
After the accession of the CEE countries, some countries in the north-west migration corridor allowed full access in 2004 and argued that very low unemployment and a great demand for mainly unskilled and low-skilled labour were the reason. This was particularly the case for the UK, Ireland and Norway that became the new target countries of the CEES system. (Sweden also opened its borders immediately, but had a relatively high unemployment and attracted much less CEE migrants). Other countries like Austria, Germany and the Netherlands, having relatively high unemployment rates, chose for transitional arrangements in order to protect their labour markets. Even more countries chose for transitional arrangements in 2007 when Bulgaria and Romania became EU-members.

The 2009 economic crisis changed the balance of push and pull factors completely. In the destination countries, the first crisis of 2009-10 hit both the west and south migration corridors of the CEES system; unemployment increased and the demand for workers fell. Inflow of foreign workers decreased and return grew. After 2010 the situation changed again: some north western countries, Germany particularly, emerged from the crisis and attracted CEE migrants again, albeit on a more modest scale than before. This was in sharp contrast with the countries in the south where economic crisis deepened, leading to huge unemployment numbers and an increasing emigration of both native and immigrant workers (Arango 2016).

This was the mirror image of the perspective of the emigration countries where "outflows from Poland decreased substantially (...) after 2008, when better domestic employment rates were recorded at the same time as the deterioration of the economic situation in receiving countries such as Ireland" (Dhéret et al. (2013: 17). Other indicators of labour market drivers had also converged significantly between 2004 and 2007: In Poland for example, wage differentials increased from 21.5 to 25.4 per cent in EUR at exchange rate (with average EU15); employment rose from 51.2 to 57.0 per cent and unemployment decreased from 17.9 to 9.6 per cent. These observations make Galgóczi et al. (2009: 11) conclude that "differences in overall labour market performance, initially substantial, have shown remarkable convergence between A8 and EU15 countries". This is surely the case, but on balance it seems fair to conclude that the strong changes in the CEES system since 2008 have been caused more by pull factors falling away than by decreasing push factors.

\subsubsection{The Organisation and Selectivity of Labour Migration}

How were individuals - in situations where the economic conditions of push and pull are fulfilled - drawn into a labour migration system. How were supply of and demand for work brought together? What did the organisation of labour migration mean for those who moved when, under what conditions and with what strategy?

In the case of the GWS system, the literature suggests that there were two main ways of getting into the system. The first was based on informal networks between individuals in sending and receiving countries through which information was passed on possibilities to work elsewhere; people in such networks received and 
supported new arrivals and mediated in finding work. There is an abundance of descriptions in the literature of the 'pioneers' who came 'spontaneously' (i.e. without a prior invitation for work), found work (and received a work and a residence permit) and started to bring over kin and fellow countrymen on request of their employer, leading to strong concentrations of workers from the same villages and regions in certain cities in receiving countries on the aggregate level (see AbadanUnat et al. 1976 and Den Exter 1993 for Turks in the Netherlands and Engelbrektsson 1978 for Turks in Gothenburg, Sweden). From a broader perspective, it also tells us that earlier migrations from certain regions in sending countries, such as pre-war labour migration from Southern Europe to Switzerland, France and Belgium could easily be revived on the basis of networks stemming from these earlier migrations.

The second way of entering the system was through the institutionalised system of labour recruitment. This system involved strong governmental participation of both sending and receiving countries through bilateral agreements on how and under what conditions workers would be recruited. It might even imply - as in the case of Turkey - that sending countries registered candidates and selected them to be sent to recruitment offices of destination countries. For those who were selected, special cheap worker passports were issued. It also implied approval of demands for recruitment by governments of receiving countries. For the selected workers contracts, work and residence permits were pre-arranged.

The Turkish case (Abadan-Unat et al. 1976; Akgündüz 2008) shows how the originally spontaneous character of migration through informal networks was gradually incorporated in the official system through the so-called "nominative contracts' (through which an employer could officially recruit a certain person whom he knew through workers he already employed). Nevertheless, the official system did not replace the spontaneous migration completely, because the waiting list for official recruitment in Turkey grew so long that the chances to be recruited became slim. Going as a 'tourist' and using the informal system thus remained in place so long as there were lenient policies to get a work and residence permit in destination countries. However, in the late 1960s such policies became stricter, thereby creating the phenomenon of illegal work (no work permit) and illegal workers (no residence permit) for the first time.

The organisation of migration as described above had consequences for the selection of migrants involved. Migration originally started in cities, but spread to rural areas later; in Morocco and Turkey this was also a consequence of the sending governments' policy. In general, the work for which guest workers were sought was production work in well-regulated industrial sectors for which no or limited skills were needed. In general, male workers were sought and recruited; female workers only in special cases for specific work. Official recruiters in Turkey and Morocco preferred married men, who were looked upon as more responsible than unmarried youngsters. Spontaneous migration could lead to over-qualification, particularly when migrants were pushed out of their country for reasons other than work but used the guest worker status to leave, such as those who fled the authoritarian regimes of Salazar, Franco or the Greek colonels in the 1960s and early 1970s. 
The official recruitment system, however, did not lead to large-scale placement of workers below their qualification level.

The development of the organisation of labour migration is different in the case of the movements from CEE countries to Western and Southern Europe and thus the selection of movers differs. When the exit opportunity opened in CEE countries after 1989, certain specific groups could and did use historical links to move. This was the case with certain regions in the CEE countries with German-speaking people who had either migrated from Germany in the past or had other ties with Germany. (Germany's Aussiedler return policy made it possible for some people of such regions, particularly in Poland, to come to Germany before 1989). Most migrants, however, had to find new routes or destinations without historical ties to guide and support them.

The movements of such new migrants from CEE countries in the period of 1989 to 2004 have followed distinctive patterns within the two migration corridors, when it comes to the question of how the migration was organised. In the first corridor of movements to Western European countries, destination countries put in place strict regulated labour recruitment programmes, mostly for temporary or seasonal work. Germany developed such migrant workers' programmes, particularly for workers from Poland, but other countries too, like France, Belgium and Switzerland; later Spain, ${ }^{3}$ Greece, Norway and the Netherlands also introduced specific bilateral programmes to facilitate temporary labour migration, often for the purposes of seasonal work (Engbersen et al. 2010a: 8 Glorius et al. 2013: 7/8). This pattern of regulated programmes resembled the official recruitment and deployment of guest workers two decades earlier.

Within this first corridor a less formal, partially legal and mostly unregistered way of work migration was practised as well, as described by Fihel and GrabowskaLusinska (2014: 23):

"Institutional barriers introduced (...) by key receiving countries located in Western Europe and North America imposed a specific pattern of mobility on Polish nationals: migration comprised repetitive, short stays abroad that coincided with seasonal and temporary employment of migrants in agriculture, construction or domestic services (...). In order to not exceed the three-month (non-visa) stay in Western European countries, Polish nationals temporarily returned home only to re-embark, soon afterwards or following a short lag, depending on economic circumstances, on another trip abroad". This has been named 'incomplete migration' by Okolski (2001).

In the second corridor of movements, to the Southern European countries, migration took an entirely different form: irregular flows. Italy, Spain, Portugal and Greece had become attractive not only to returning emigrants in the 1980s, but also to migrants from Eastern Europe in the 1990s. The large informal sector (agriculture, building, tourism and domestic work) and the labour-intensive manufacturing

\footnotetext{
${ }^{3}$ For Spain and Greece these state-led labour migration programmes have been only a small part of the total CEE labour immigration; by far most labour migrants followed the irregular pattern; see below.
} 
sector of their economies attracted many migrants from Romania, Ukraine, Albania and Bulgaria (King et al. 1997; Peixoto et al. 2012). These flows resembled the spontaneous migration of the GWS system in its first phase: informal networks providing information and support and building up chains between regions of origin and destinations. Lenient admission regimes made it easy to enter the southern destination countries. Frequent and massive regularisations legalised most of these migrants over the course of time. In addition to informal networks, intermediaries and agencies in the private sector developed to connect the demand and supply. State regulation and control were nearly absent, apart from the small quota for recruitment (see above).

The accession to the EU of eight CEE countries in 2004 and of Bulgaria and Romania in 2007 changed the patterns outlined above significantly. First of all, it legalised the migrant populations that had reached the EU15 countries in irregular ways before, particularly in the southern countries. Secondly, it created new flows to those EU15 members that opened their borders without transitional arrangements within a short time. The pull factor of low unemployment and ample opportunities for work (until the economic crisis in 2009) in the UK, Ireland and Norway particularly attracted many workers from CEE countries. In this new context of great demand for workers, the absence of restrictions on entrance and access to the labour market and a neo-liberal political climate of deregulation, private agencies quickly found a new market of connecting demand and supply; they mushroomed "and made a lot of money" (Jones 2014).

Flows to EU15 countries that had opted for transitional arrangements for the introduction of free movement of workers also increased after 2004, notwithstanding the delayed free movement. The population of Polish workers in the FRG and the Netherlands, for example, increased significantly between 2004 and 2008. Newcomers often used alternative strategies to circumvent the limitations to free movement, such as coming as self-employed entrepreneurs or being sent as posted workers (in both cases using the freedom of service provision in the EU: see Galgóczi and Leschke 2015: 8). In such cases, the social networks of the resident immigrant population and the infrastructure of intermediaries and work agencies were used to employ posted and self-employed workers.

Literature on the consequences of the way migration was organised in the CEES system is ever growing and it poses the following questions: who moved, with what motivation and strategy, and with what intentions for the future. Our central question remains: what makes the movements in the CEES system different from those in the GWS system?

The first element of difference is the less prominent - and sometimes even completely absent - roles of state control and regulation on the one and the significance of private- or market-driven intermediaries and work agencies (including smugglers and traffickers in some circumstances) on the other hand. The latter organise the connection between supply and demand, often resulting in less protected ways of labour migration or work mobility. In comparison with the GWS system only a small portion of CEE labour migration went through official, state-led or controlled programmes that not only connected supply and demand, but also clearly regulated 
legal statuses, work conditions and remuneration - on a par with local conditions for natives. The CEES has a multitude of legal statuses (including a large portion who lack a legal status at least temporarily), many of these imply a great vulnerability on the routes toward and on the new labour markets. In CEES private intermediaries (who are sometimes illegal) and agencies operating in both sending and receiving countries discovered a profitable market. These agencies played an important role, not only in connecting supply and demand, but also in actively recruiting workers. Furthermore the work that they offered more often than not was located in new and (for workers) less protected segments of the labour market.

Such a system is attractive and profitable for candidate migrants in a different way than GWS. The GWS system was more demand-driven in its organisation and future employers recruited selected workers under conditions that implied more protective elements: for workers there was less choice, but relatively more certainty and protection. In the CEES system, there seemed to be more options and alternatives for workers, but the options were less certain and unprotected. The selectivity among the candidates in the CEES system is therefore based on the question of who sees advantages in work abroad that is temporary and uncertain, and how does a choice for such work fit into the migrant's plan for the future.

That leads to another characteristic of CEE migration, namely the multitude of (labour market) strategies that migrant workers follow. For example, Glorius et al. (2013: $315 \mathrm{ff}$ ) mention 'target earners' and 'circular migrants' that seem to fit within the concept of temporary labour migration, but they also find 'career seekers', students and young (often urbanized) educated migrants ('adventure seekers' or 'drifters') whose migration trajectory is different and unpredictable.

According to Fihel and Grabowska-Lusinska (2014: 23), characteristics of incomplete migration and the unpredictability of migrant decisions to remain in a host country, return home or move to another country are also valid after 2004, as is the uncertainty of the meaning of return. This uncertainty is reflected in the various strategies that migrants have, such as a) reconciling employment opportunities in Poland and abroad; b) giving up jobs in Poland to work abroad temporarily; c) replacing inactivity in Poland with work abroad; d) starting a business at home after migration (Fihel and Grabowska-Lusinska 2014: 28-30).

The typologies above are based on the labour market perspective of the country of origin. Engbersen et al. (2013) made a typology of migrants in which strong or weak ties with the countries of origin and destination are combined and they have come up with four types: circular migrants; bi-national migrants; footloose migrants and settlement migrants. All four types can be found, although sometimes in unexpected combination with, for example education.

This hints at yet another characteristic of CEE migrants: their level of education. In literature we have found that also students and professionals participated in the temporary and seasonal work programmes before 2004. After 2004, the average educational level of movers seems to have increased: "An important new trend of post-2004 labour mobility is the fact that migrants from low-wage countries [within the EU] generally have comparably high educational profiles, also in relation to nationals in the receiving countries" (Galgóczi and Leschke 2015: 8-23). 
The high educational levels combined with labour markets that offer low-skilled jobs lead to the claim that "skills/occupation mismatch is an important characteristic of post-2004/2007 intra-EU migration; this claim has been substantiated by the current sectoral distribution of migrant labour, which focuses overwhelmingly on sectors that do not require a higher education" (Galgóczi and Leschke 2015: 8-23).

Researchers looking at the aggregate flows and at the motivations and strategies of the migrants involved have stressed that east-west labour migration in Europe "is becoming increasingly diverse, fluid and sub-regionalised in nature (Napierala and Trevena 2010)." Engbersen et al. (2010a: $11 \mathrm{ff}$ ) have coined the concept 'liquid migration' for such diverse and unpredictable migrations (see also Engbersen in Chap. 4 of this volume).

\subsubsection{National and EU Systems of Regulating Cross-Border Migration and Mobility}

In the preceding two sections, states and their regulatory systems have been alluded to several times. In this paragraph we will look explicitly at state regulatory systems of international migration and see whether they have played a different role in the GWS and CEES migration systems.

When the demand for migrant workers emerged in the 1950s and 1960s, they were defined as foreigners, or foreign workers, from the point of view of the migration regulatory system. Apart from Switzerland, that had a stricter policy of old, most North Western European countries had simple and lenient admission procedures in the beginning. Migrant workers came 'spontaneously', as tourists; if they found work they would be given a work permit. Having a work permit would enable them to get a residence permit. After the economic recession of 1966/67 however, most destination countries started to apply more control to the system of admission. In the Netherlands, for example, permission for legal entrance and a residence permit had to be arranged with a Dutch Embassy or Consulate in the country of origin before arrival in the Netherlands since 1969. Introducing this new system of control also made it possible to implement the actual labour migration stops between 1972 and 1974. In the second half of the 1970s these stricter policies for residence and work permits, combined with the stop on labour migration, led to the emergence of undocumented migrants and the call for regularisations.

Within the legal regulatory system described above, the state (i.c. the ministry responsible for employment) gradually built an institutional system for recruitment and deployment of workers from abroad: bilateral agreements between recruiting and sending countries were concluded in which rules, conditions and procedures were established. Institutional arrangements and policies were elaborated at the sending and the receiving side. Turkey gave emigration a place in its national economic planning, for example, and developed a registration system for candidate migrant workers and proposed selected candidates to foreign recruitment offices (Akgündüz 2008). At the receiving end, recruitment procedures were developed by 
state agencies and implemented by recruitment or immigration offices. In countries where trade unions had acquired strong positions in tripartite socio-economic decision-making, such as Austria, the FRG, the Netherlands and Sweden, labour unions were actively involved in controlling and setting the conditions for recruitment and employment of these migrant workers (Penninx and Roosblad 2000; Rist 1978).

The regulatory system of the CEES system saw a completely different development than that of the GWS system. In the early 1990s the legal infrastructure still resembled the one that was in place towards the end of the GWS system. On the one hand, CEE countries of origin had opened the exit option for its citizens after the fall of the Iron Curtain (which before had been open only for migrant workers from Yugoslavia in the GWS system). On the other hand, European Community countries (totalling 12 in 1990) theoretically installed the same restrictive immigration policies for third-country nationals (TCNs) that had been developed in the destination countries of the former GWS system: new EC members, like Greece, Spain and Portugal, had created similar legal regulatory systems as part of the requirements to become an EU member: the acquis.

However, under this formally unitary legal system, two quite different implementation regimes developed within the European Community and later the EU (Doomernik and Bruquetas-Callejo 2015: 61ff). The first is the North Western European regime that had developed from an initially open 'guest worker system' in the 1960s towards an increasingly controlled, restrictive and selective admission policy for foreign workers after 1974. CEE labour migration to these countries under this regime in the period 1990-2004 took the form of specific but limited labour immigration programmes on the one hand, and short-term circular labour on tourist visa and irregular work migration on the other.

The second implementation regime in that same period was established in the Southern European countries (see chapters on Italy and Spain in Zincone et al. 2011). In the words of Doomernik and Bruquetas-Callejo (2015: 61), this regime is characterized "by a predominance of labour and family migration, scarcity of asylum seekers, illegality as an endemic feature, and the combination of restrictive admission and citizenship policies with frequent amnesties." Under this regime labour migrants were mainly attracted and absorbed by the informal economy. The state is not an actor in the regulation of migration, while private intermediaries and agencies play an important role in the organisation.

In previous analyses of labour migration policies in Europe, states were the basic units for analysis, workers were defined as international migrants who cross state borders and states had the sovereign right to decide whether foreign workers are allowed to reside and work there. Over the course of time, however, a completely different legal regime for mobility has been developed for and within a supranational unit in Europe: the European Union (Penninx 2014). Its predecessors, the European Coal and Steel Community (ECSC, since 1951), the European Economic Community (EEC, since 1968), and the European Community (EC, since 1985) had gradually created an area in which former international migration between member states was actually transformed into internal migration and mobility. This process 
was finalised in the European Union (EU, since 1993) that gave all citizens (and long-term legally residing TCNs) complete freedom of movement and the freedom to work in all member states.

This new intra-European movement regime was in place when the EU expanded from 15 members (since 1995) to 25 members in 2004, to 27 in 2007 and to 28 in 2013, when Croatia joined the EU. Although many EU15 member states delayed free access of citizens to the labour market of these new members for some years, by 2014 the freedom to work had been realised in all 28 EU-countries, except Croatia. This changed the basics of the regulatory system and the role of states in migration and mobility in general, and of labour migration systems in particular. In the economy-driven ideology of the EU, the national labour markets of all EU countries have merged into a single market where market mechanisms and agencies are supposed to do their work without the hindrance of borders and of national authorities and legislations. International migration has become internal mobility: an economically profitable and desirable situation. Ideally, it means that individual citizens have an unlimited choice - on principle - to go and work elsewhere in the EU for whatever reason, with whatever intention to stay or return; and employers, agencies and intermediaries, in turn, are working in an open competitive market, unhindered by protective state or national labour market regulations.

In actual practice, however, the picture is somewhat different: the unrestricted choice for the worker should be put in the perspective of the greater precariousness of the work on offer (as compared between the CEES and the GWS). At the same time, the absence of national restrictions to open, intra-European competition is resisted vehemently by trade unions and sometimes even national governments. Using national protective systems they want to defend equality of workers against 'social dumping', such as the posting of workers under foreign rules, outsourcing work to agencies or the use of 'bogus self-employed entrepreneurs'.

All in all, it is clear that the principles, regulations and practical mechanisms of free movement of workers in deregulated and segmented labour markets are quite different from the ones that governed the Guest Worker System. The outcomes in terms of the nature and direction of flows, of who participates in the movement with which motivation and which strategy, and where participants in the movement ultimately end up are bound to be different.

This fundamental difference between the GWS and CEES systems, in terms of state regulation also had consequences for the cities and towns in which migrants came to work. The strong involvement of the state and social partners in the regulation and control of guest workers deployment implied an employers' and state responsibility for the housing of recruited workers. Big companies often built residential accommodation (sometimes on the premises of the work place) or hired these elsewhere, and the national state could take the initiative to build special residences within national building plans, as was the case in the Netherlands in the 1970s. Furthermore, the state subsidised social and welfare work for guest workers, in the Dutch case for example through a network of regional Foundations for Assistance to Foreign Workers and its umbrella organisation LSBBW (later NCB). In the case of migrant workers from CEE countries, particularly after 2004, employ- 
ers or the state did not take on such responsibilities. Cities and towns had to deal with the housing and social demands of these migrant workers, using their own services and budgets. Claims of local governments on state budgets for costs of such services to CEE migrants have been to no avail generally speaking.

\subsection{Conclusion}

At face value, the guest worker migration system of 1955-1974 and the migration system from CEE countries to EU15 countries in the period 1990-2015 do have some basic resemblances: both entail a number of sending countries with economies and labour markets that push workers to go elsewhere. These countries are connected to a number receiving countries that have healthy economies and (selective) labour market shortages that pull workers. In both the GWS system and the CEES system millions of workers have been involved, often including periods of work that were followed by a definitive return. The time frame of 2.5 decades in both systems also led to resident immigrant populations of not only workers in receiving countries, partially settling immigrants.

Comparing economic and labour market factors that form a necessary condition for the emergence and continuation of labour migration systems in more detail, we see a strong resemblance again. The differential development gaps (measured in GDP per capita) between sending and receiving countries in both systems during and at the end of both systems are strikingly similar. Even the differentiation of countries at the sending side is comparable: in the GWS system Turkey compares with Poland, Romania and Bulgaria in the CEES, as they are all countries with a GDP per capita of around $20 \%$ of the destination countries. The Southern European countries within the GWS also had comparable gap figures as the better-performing countries in the CEES like Slovenia and the Czech Republic. Other indicators, such as unemployment and activity rate, suggest a comparability of the two systems as well. The ending of the GWS system in 1974 and the end of the growth of the CEES system in 2009 are not so much caused by changes at the push side (with decreasing GDP- and wage differentials) in sending countries, as by a sudden disappearance of pull factors in destination countries during the economic crises starting in 1974 and 2008 respectively.

Nevertheless, when comparing the organisation of the migration movements in combination with the legal regulatory framework and state policies regarding labour migration, we see very different regimes of regulating labour migration, going together with very different forms of the practical organisation of flows. The GWS had started as a movement of workers moving along informal networks that connected workers and future employers in a context in which the spontaneous arrival could be legalised easily and under regular conditions of the labour market. In the course of time, this labour migration became institutionalised, implying a stateled - often tripartite - decision-making on recruitment and on conditions for regular work and residence. That system was also able to canalize to a great extent the 
informal system through nominative recruitment. It could imply involvement of the sending state in recruitment, regulation and protection, as was the case in Turkey. Private intermediaries and work agencies were virtually absent in this institutionalised system.

In the CEES system both the legal context and the organisation were different. In the first period of 1990 to 2004 there were at least three quite different ways of participating in labour migration: in the North Western European corridor there were (limited) formalised labour migration programmes that resembled the official recruitment of the GWS system, but the bulk of labour migration consisted of the quasi-legal short-term and repeated work visits that was coined incomplete migration. Private market intermediaries and work agencies (both legal and illegal) played an important role in these movements. In the southern migration corridor, movements took the form of irregular labour migration through informal channels, and became increasingly organised and assisted by (illegal) intermediaries and agencies, without involvement, consent or cooperation of authorities in destination countries. This labour migration mainly served the informal and low-wage sectors of the economies in the south.

After the accession of CEE states in 2004 and 2007, the legal context changed drastically in the sense that legal barriers for movement gradually disappeared. In the new free mobility market, connecting the supply of workers in CEE countries with a growing demand for flexible work in the booming neo-liberal economies of the west and south, was a profitable activity for intermediaries and work agencies. Regulation and control of movement by national authorities was supposed to be absent after transitional periods (but even before that time), even when migrant workers' protection became endangered by new practices of deploying foreign workers by posting or so-called self-employment. This heyday of the CEES ended abruptly in 2009 by the economic crisis.

The literature documents the differential effects of the new legal framework and the different organisation that came with it: who was selected, who made himself available as a migrant in the system, and how did migrants use that system for their short and long-term future? The GWS generally brought in low-skilled, predominantly male migrants for certain periods for regular jobs at the lower end of the formal labour market for relatively well-protected contract work. In the CEES the regular organised labour migration programmes were a minor part of the movement and only in the first phase. In the first phase, until 2004, most of the movement was irregular - in the sense that a pre-organised legal frame was absent - and not officially organised - in the sense that demand and supply was connected through informal networks or (often irregular) private intermediaries and agencies. The actual work obtained was often irregular, less protected and certain, and low paid.

Such different opportunities have obviously attracted different candidates who could fit these opportunities to their varied migration strategies. Women participated much more than in GWS. The age variation is larger. Migrants in CEES turn out to be relatively well educated, but work below their skills. These trends seem to be reinforced after 2004, when the legal barriers obstructing labour mobility had disappeared. The result is an increasingly heterogeneous movement of people who use 
temporary, uncertain work in the west or south as a means of exploring how their future might look and where it could happen. It is certainly not a labour migration system as the one defined in the literature: not only the new bottles of the CEES are different from the older ones of the GWS, the wine tastes different as well.

The outcome, where these mobile people of the CEES will end up establishing themselves is rather unpredictable. The ones who are successful in their new places of residence will probably be inclined to stay. But who knows the percentage of successful migrants (basically those that find a steady job corresponding with the skill level and ambition of the migrant and better than staying in their home country)? In the North Western European countries and economies, chances of success do not appear to be any better now than they were for guest workers in the past. In the crisis-ridden Southern European countries, chances seem even slimmer. One basic difference with the GWS system is that none of the CEE migrants will stay in destination countries because a return home would make it impossible to depart anew. Free mobility within the EU will prevent that unexpected outcome of strict regulation (for Turks and Moroccans) after the end of the GWS system in 1974.

\section{References}

Abadan-Unat, N., Keleş, R., Penninx, R., van Renselaar, H., van Velzen, L., \& Yenisey, L. (1976). Migration and development: A study of the effects of international labor migration on Boğazllyan district. NUFFIC: Den Haag/Ankara.

Akgündüz, A. (2008). Labour migration from Turkey to western Europa, 1960-1974; a multidisciplinary analysis. Aldershot: Ashgate.

Arango, J. (2016),Spain: New Emigration Policies Needed for an Emerging Diaspora. At: http:// www.migrationpolicy.org/research/spain-new-emigration-policies-needed-emerging-diaspora

Black, R., Engbersen, G., Okolski, M., \& Pantiru, C. (Eds.). (2010). A continent moving west? EU enlargement and labour migration from central and Eastern Europe. Amsterdam: Amsterdam University Press.

Bonifazi, C., Okolski, M., Schoorl, J., \& Simon, P. (Eds.). (2008). International migration in Europe: New trends and new methods of analysis. Amsterdam: Amsterdam University Press.

Cohen, R. (1987). The new helots; Migrants in the international division of labour. Vermont: Gower.

Den Exter, J. (1993), Regionale herkomst van Turken in Nederland, in: Migrantenstudies 9, nr 3, 18-34.

Dhéret, C., A. Lazarowicz, F. Nicoli, Y. Pascouau \& F. Zuleeg (2013), Making progress towards the completion of the Single European Labour Market. Brussels: European policy Centre, EPR Issue Paper no. 75.

Doomernik, J., \& Bruquetas-Callejo, M. (2015). National immigration and integration policies in Europe since 1973. In B. Garcés-Mascareñas \& R. Penninx (Eds.), Integration processes and policies in Europe. Contexts, levels, actors (pp. 57-76). Dordrecht: Springer Open.

Engbersen, G., Okolski, M., Black, R., Godfried, E., \& Pantiru, C. (2010a). Introduction: Working out a way from east to west: EU enlargement and labour migration from central and Eastern Europe. In R. Black, G. Engbersen, M. Okolski, \& C. Pantiru (Eds.), A continent moving west? EU enlargement and labour migration from central and Eastern Europe (pp. 7-22). Amsterdam: Amsterdam University Press.

Engbersen, G, E. Snel \& J. de Boom (2010b), A van full of poles': Liquid migration from central and Eastern Europe'. In: R. Black, G. Engbersen, M. Okolski \& Chr. Pantiru (Eds), A continent moving west? EU enlargement and labour migration from central and Eastern Europe. Amsterdam: Amsterdam University Press, pp. 115-140. 
Engbersen, G., Leerkes, A., Grabowska-Lusinska, I., Snel, E., \& Burgers, J. (2013). On the differential attachments of migrants from central and Eastern Europe: A typology of labour migration. Journal of Ethnic and Migration Studies, 39(6), 1-23.

Engelbrektsson, U.-B. (1978). The force of tradition; Turkish migrants at home and abroad. Gothenburg: Acta Universitatis Gothoburgensis.

Eurostat. (2011). Migrants in Europe. A statistical portrait of the first and second generation. Luxembourg: Publications Office of the EU.

Fawcett, J. T. (1989). Networks, linkages, and migration systems. The International Migration Review, 23(3), 671-680.

Fihel, A., \& Grabowska-Lusinska, I. (2014). Labour market Behaviours of back-and-forth migrants from Poland. International Migration, 52(1), 2014.

Fihel, A., \& Okolski, M. (2009). Dimensions and effects of labour Migrtaion to EU countries: The case of Poland. In B. Galgóczi, J. Leschke, \& A. Watt (Eds.), EU labour migration since enlargement: Trends, impacts and policies (pp. 185-210). Aldershot: Ashgate.

Galgóczi, B, \& J. Leschke (2015). Free movement of labour in Europe: a solution for better labour allocation? Brussels: ETUI, Working Paper 2015.06.

Galgóczi, B., Leschke, J., \& Watt, A. (2009). Intra-European labour migration - Flows and policy responses. In B. Galgóczi, J. Leschke, \& A. Watt (Eds.), EU labour migration since enlargement: Trends, impacts and policies (pp. 1-28). Aldershot: Ashgate.

Glorius, B., Grabowska-Lusinska, I., \& Kuvik, A. (Eds.). (2013). Mobility in transition; migration pattern after EU enlargement. Amsterdam: Amsterdam University Press.

Hars, A. (2009). Dimensions and effects of labour migration to EU countries: The case of Hungary. In B. Galgóczi, J. Leschke, \& A. Watt (Eds.), EU labour migration since enlargement: Trends, impacts and policies (pp. 229-252). Aldershot: Ashgate.

Jones, K. (2014, December). 'It was a Whirlwind. A lot of people made a lot of money': The role of agencies in facilitating migration from Poland into the UK between 2004 and 2008. Central and Eastern European Migration Review, 3(2), 105-125.

King, R., Fielding, A., \& Black, R. (1997). The international migration turnout in Southern Europe. In R. King \& R. Black (Eds.), Southern Europe and the new immigrations (pp. 1-25). Brighton: Sussex Academic Press.

Markova, E. (2010), Optimising migration effects: A perspective from Bulgaria, In: R. Black, G. Engbersen, M. Okolski \& Chr. Pantiru (Eds), A continent moving West? EU enlargement and labour migration from central and Eastern Europe. Amsterdam: Amsterdam University Press, pp. 207-230.

Napierala, J., \& Trevena, P. (2010). Patterns and determinants of sub-regional migration: A case study of Polish contruction workers in Norway. In R. Black, G. Engbersen, M. Okolski, \& C. Pantiru (Eds.), A continent moving west? EU enlargement and labour migration from central and Eastern Europe (pp. 51-72). Amsterdam: Amsterdam University Press.

Okolski, M. (2001). Incomplete migration. A new form of mobility in central and Eastern Europe. The case of Polish and Ukrainian migrants. In C. Wallace \& D. Stola (Eds.), Patterns of migration in Central Europe. Houndmills/Basinstoke: Palgrave Macmillan.

Okolski, M. (Ed.). (2012). European immigrations: Trends, structures and policy implications. Amsterdam: Amsterdam University Press.

Peixoto, J., J. Arango, C. Bonifazi, C. Finotelli, C. Sabino, S. Strozza \& A. Triandafyllidou (2012), 'Immigrants, markets and policies in Southern Europe; the making of an immigration model?. In: B. Glorius, I. Grabowska-Lusinska \& Aimee Kuvik (Eds) (2013),Mobility in transition; Migration pattern after EU enlargement. Amsterdam: Amsterdam University Press, pp. 107-148.

Penninx, R. (2014). Regional economic integration and migration: Lessons from the case of Europe. In G. Battistella (Ed.), Global and Asian perspectives on international migration (pp. 183-196). Cham: Springer International Publishing. 
Penninx, R., \& Roosblad, J. (Eds.). (2000). Trade unions, immigration, and immigrants in Europe, 1960-1993: A comparative study of the attitudes and actions of trade unions in seven Western European countries. New York/Oxford: Berghahn Books.

Potot, S. (2010). Transitioning strategies of economic survival: Romanian migration during the transition process. In R. Black, G. Engbersen, M. Okolski, \& C. Pantiru (Eds.), A continent moving West? EU enlargement and labour migration from Central and Eastern Europe (pp. 249-270). Amsterdam: Amsterdam University Press.

Rist, R. C. (1978). Guestworkers in Germany; The prospects for pluralism. New York: Praeger Publishers.

SVR (Sachverständigenrat deutscher Stiftungen für Integration und Migration). (2013). Erfolgsfall Europa? Folgen und Herausforderungen der EU-Freizügigkeit für Deutschland. In Jahresgutachten 2013 mit Migrationsbarometer. Berlin: SVR.

Van Mol, C., \& de Valk, H. (2015). Migration and immigrants in Europe: A historical and demographic perspective. In B. Garcés-Mascareñas \& R. Penninx (Eds.), Integration processes and policies in Europe. Contexts, Levels, Actors (pp. 31-55). Dordrecht: Springer Open.

Zincone, G., Borkert, M., \& Penninx, R. (Eds.). (2011). Migration policymaking in Europe; The dynamics of actors and contexts in past and present. Amsterdam: Amsterdam University Press.

Open Access This chapter is licensed under the terms of the Creative Commons Attribution 4.0 International License (http://creativecommons.org/licenses/by/4.0/), which permits use, sharing, adaptation, distribution and reproduction in any medium or format, as long as you give appropriate credit to the original author(s) and the source, provide a link to the Creative Commons license and indicate if changes were made.

The images or other third party material in this chapter are included in the chapter's Creative Commons license, unless indicated otherwise in a credit line to the material. If material is not included in the chapter's Creative Commons license and your intended use is not permitted by statutory regulation or exceeds the permitted use, you will need to obtain permission directly from the copyright holder.

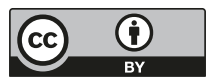

